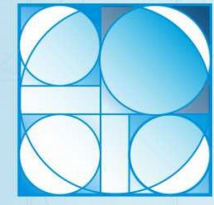

Editorial

\title{
Editorial $2018-2$
}

O segundo semestre de 2018 foi marcado pelo lançamento do edital REB/SBBq do 2o Prêmio Nacional de Ensino de Bioquímica e Biologia Molecular Bayardo Baptista Torres, a partir do qual esperamos incentivar o compartilhamento de boas e inovadoras práticas para o ensino básico e superior.

O segundo número de 2018 conta com cinco artigos, distribuídos em três seções: "Inovações Educacionais"; "REB na Escola"; e "Imagem Pública e Divulgação Científica". Cada vez mais recebemos artigos associando os conteúdos de Bioquímica, Genética e Fisiologia, com abordagem molecular visando o ensino básico e superior. É o reconhecimento crescente da importância de, cada vez mais, integrarmos os diferentes aspectos do conhecimento para a compreensão dos processos biológicos, da ciência e da vida em si.

Na seção "Inovações Educacionais" há dois trabalhos, o primeiro apresentando um jogo para ensino de conceitos básicos de Genética para estudantes do nível médio ou superior (introdutório) e o segundo apresentando uma proposta de ensino híbrido com aplicação de gamificação para o ensino de Bioquímica.

Na seção "REB na Escola" há dois trabalhos que trazem experiências interessantes em escolas. O primeiro focado no ensino de Ciências, 60 e 70 ano do fundamental, a partir de testes de plantas medicinais com o modelo experimental de Artemia salina e o segundo trabalho descrevendo sequências didáticas para o ensino do ciclo celular, para estudantes do ensino médio (disciplina de Biologia).

Na seção Imagem Pública e Divulgação Científica" apresentamos uma experiência de projeto de extensão envolvendo atividades interativas com foco em conceitos da Biologia Molecular, como estruturas de moléculas, DNA etc.

Este número apresenta uma diversidade rica de experiências e práticas de ensino, desde o fundamental até o superior, trazendo novos elementos, formas de compreender ou mesmo dando visibilidade para práticas realizadas nas escolas.

Lembrem-se, cada discente, docente, pesquisador ao ter ideias inovadoras poderia compartilhálas com a comunidade. Portanto, todos estão convidados a divulgar suas propostas na Revista de Ensino de Bioquímica.

Atenciosamente

Gabriel G. Hornink

Unifal-MG

Editor-chefe

Vera Maria T. Trindade

UFRGS

Co-editor
Bayardo B. Torres

USP

Editor-sênior

Eduardo Galembeck

Unicamp

Co-editor
André Amaral Branco

Unifesp

Co-editor 